\title{
Factors Influencing the Value of CPD Activities Among VET Teachers
}

\author{
Per Andersson*, Mattias Hellgren, and Susanne Köpsén \\ Linköping University, Department of Behavioural Sciences and Learning, \\ SE-581 83 Linköping, Sweden
}

Received: 01.12.2017; Accepted: 16.03.2018; Published: 30.08.2018

\begin{abstract}
Context: Teachers in vocational education and training (VET teachers) have specific conditions for their continuing professional development (CPD). They have a background in an initial occupation, in which they now teach and train the next generation. Thus, as VET teachers, they are expected to master the knowledge and skills of that occupation, even if they have now crossed the boundary from the community of their initial occupation to the community of the school. This study explores the perceived values among VET teachers of different activities that may contribute to their CPD in teaching subjects/initial occupations. The study examines VET at the upper secondary level in Sweden. Here, the VET teachers have the main responsibility for students' vocational learning in the vocational subjects, including the work-based parts. In the latter parts, the teachers are supplemented by supervisors at the workplace.
\end{abstract}

Approach: We argue for the duality of a VET teacher identity with a professional competence that comprises two intertwined parts - teaching skills, and knowledge of the teaching subjects based in the teachers' initial occupations. Our study is based on a situated learning perspective, and the empirical findings particularly concern values created from learning through participation and boundary crossing. CPD activities typically include some form of participation in and/or boundary crossing between school and work-life practices. In the analysis we also include the possible influence of institutional, situational, and dispositional drivers and barriers for participation in different activities. The research question was: what factors can explain the variation in perceived values created by participation in different CPD activities among VET teachers? The study was conducted as a survey of 886 Swedish VET teachers. Focus was put on the values

${ }^{*}$ Corresponding author: per.andersson@liu.se

ISSN: 2197-8646

http://www.ijrvet.net 
created through different types of activity, values for the teachers' vocational knowledge, for networks in working life, and for teaching. The data were primarily analysed using logistic regression modelling.

Findings: Dispositional drivers, the teacher's sex, and regular performance of the activity are important for the perceived value. The dispositional factor is the one most commonly retained, and it has a consistently positive effect. Factors such as educational background and vocational training have weaker influence, which suggests that individual driving factors are important when VET teachers assess the value of CPD activities.

Conclusions: The study covers a general challenge for VET teachers, but is of particular relevance in systems with a high degree of school-based VET, full-time employed VET teachers, and VET teachers who are responsible for students' vocational learning. Here, the values for vocational knowledge, for networks, and for teaching that are created through different activities are important for the VET teacher identity. They are also interrelated, and together they provide professional development in relation to the initial occupation, and for the occupation as a vocational teacher.

Keywords: VET, Vocational Education and Training, Continuing Professional Development, Value Creation, Vocational Teachers, Staff Development

Paper Type: Research Article

\section{Introduction}

Teachers have a professional competence that comprises two intertwined parts - teaching skills and knowledge in the subject that they teach. For teachers in vocational education and training (VET), these two parts mean a dual professional competence (Fejes \& Köpsén, 2014), as the knowledge in a vocational subject in VET means professional, or occupational, competence. To maintain and develop this occupation-related subject knowledge, the VET teacher must engage in continuing professional development (CPD) that involves not only the teaching competence, but also knowledge and skills in their initial occupation.

This study focuses on VET teachers' CPD in their vocational subject. We have studied VET at the upper secondary level in Sweden. Here, two main categories of teachers are employed: those who teach general subjects such as maths, Swedish, and English; and those who teach vocational subjects. This article focuses on the latter category. The VET teachers have the main responsibility for students' vocational learning in the vocational subjects, including the work-based parts, during which teachers are supplemented by supervisors at the workplace.

VET teachers, with few exceptions, have a background in an occupation for which they now teach the next generation. Among the exceptions, in which the VET teachers normally have a higher qualification than the one their students are studying towards, are nurses who teach assistant nurses-to-be. Thus, these VET teachers have a background with a certain vocational competence and identity. However, most of them now 
have full-time employment as VET teachers, which means that they have a challenge concerning CPD to maintain and develop their vocational competence, i.e. the subject contents from the initial occupation that they are expected to master. This is a challenge for VET teachers in any national system, although the needs differ between different traditions and cultures (Brockmann, Clarke, Méhaut, \& Winch, 2008; Brockmann, Clarke, \& Winch, 2008; Grollmann, 2008). However, the issue is particularly relevant in systems in which the teachers have a high degree of responsibility for students' vocational learning, even when it is based in the workplace, as in Sweden. In, for example, the German dual apprenticeship system, the situation is different, with the companies and chambers of commerce having a dominant role with responsibility for workplace learning and examinations, while vocational schools have a subordinate role (Gessler, 2017). Nevertheless, our findings are relevant also in such systems, particularly in light of the German policy-level ambition of greater collaboration between schools and companies. Furthermore, the challenge is greater for full-time employed teachers with more limited opportunities to combine teaching with work in their initial occupation.

This study is part of a larger project, in which we have previously analysed participation in a national initiative, where grants from the Swedish National Agency of Education supported VET teachers' workplace-based CPD, by which they gain practical experience in their initial vocations, and other shorter industry-related CPD activities (Andersson \& Köpsén, 2015; Köpsén \& Andersson, 2017). Furthermore, we have analysed results from a large-scale survey among VET teachers to identify factors that influence the participation in a number of activities that have the potential to contribute to these teachers' CPD (Andersson \& Köpsén, 2017). In the present study, based on the same survey data, our focus is the outcomes or values created from these activities in terms of CPD. We are interested in what factors can explain high perceived values with respect to VET teachers' CPD. Our previous analysis (Andersson \& Köpsén, 2017) showed significant differences in perceived values between teachers whom we had categorised as "participants" and "non-participants" in the different activities. We continue the analysis here, and explore factors that can explain the variation in (perceived) values created from the CPD activities. We analyse also the effect that participation has when additional factors are included. More precisely, our research question is: what factors can explain the variation in perceived values created by participation in different CPD activities among VET teachers?

\section{Theoretical Perspective}

We argue for the duality of a vocational teacher identity, as VET teachers need to be competent in teaching and in current occupational practice related to their initial occupations (Fejes \& Köpsén, 2014). We have here not only examined CPD opportunities that may increase occupational competence, but also analysed the perceived value of such CPD for teaching. In other words, VET teachers must possess current work-life experience of the occupation related to their teaching subject in order to prepare the vocational students for working life (e.g. Köpsén, 2014; Robson, Bailey, \& Larkin, 2004). 
Our study is based on a situated perspective on learning (Lave \& Wenger, 1991; Wenger, 1998; Wenger-Trayner, Fenton-O'Creevy, Hutchinson, Kubiak, \& Wenger-Trayner, 2015), and the empirical findings particularly concern values created from learning through participation and boundary crossing. From this perspective, knowledge is seen as situated in specific communities of practice, and learning takes place through active participation in these. However, a community of practice is not stable but changing; and the possession of current knowledge, understandings and skills requires active involvement in the community of practice.

It is through movements between different communities of practice, known as "boundary crossings", in landscapes of practice, that individuals learn and develop a nexus of identities (Akkerman \& Bakker, 2011; Wenger-Trayner et al., 2015). Following our theoretical framework, we argue that such boundary crossings are particularly important in the way in which VET teachers learn and shape their vocational teacher identity (Fejes \& Köpsén, 2014).

These teachers crossed the boundary between the practice of their initial occupations and the practice of VET when they became teachers. However, they benefit from crossing this boundary back and forth during their career as a teacher, in order to maintain and develop their occupational knowledge. Thus, such boundary crossings are crucial for them to remain competent in current occupational knowledge, understanding and skills in the subject they teach. It is also probable that VET teachers benefit from boundary objects, and that participation in other communities of practice that are interconnected with the specific occupational community will contribute to updating their occupational knowledge and skills. Such participation may take the form of attending conferences, participating in networks, reading journals, running development projects in schools, or studying in further education (Broad, 2016).

We use here Cross's (1981) analysis of how institutional, situational, and dispositional barriers may influence participation in adult education or (in our case) CPD. "Institutional" factors are situated in the organisation of the VET schools and in the workplaces for which students are trained. "Situational" factors refer to the life situation of the teacher, and "dispositional" factors concern the teacher's personal motivation. These factors may also influence the extent of CPD activities.

We draw on a holistic perspective of CPD, including all the activities that teachers engage in in order to improve their work. This perspective also considers system factors (Bolam \& McMahan, 2004; Day \& Sachs, 2004). However, here the focus is participation in activities in which VET teachers can develop vocational or occupational knowledge that is current in the industry. Furthermore, we include activities that can enhance their knowledge and skills even though not designed for this - in other words informal and unintentional professional development (Eraut, 2007; Fraser, Kennedy, Reid, \& Mckinney, 2007).

The particular focus of the present study is the outcome of different types of participation and boundary crossing for VET teachers' CPD. In other words, we analyse the values created from such activities, "the value of the learning enabled by community involvement and networking" (Wenger, Trayner, \& de Laat, 2011, p. 7). More precisely, we study how the respondents perceive the way in which CPD is valuable to them. 


\section{Prior Research}

Research on teachers' CPD in general is extensive, and an overview of this field is beyond the scope of the present article with its focus on VET teachers. But it is important to point out, as Fraser et al. (2007) do, that different sites of learning should be taken in consideration, and not only what has "been traditionally valued as probable sites for teacher learning" (ibid., p. 167). Furthermore, all teachers' learning includes a number of different and more or less connected domains: pedagogy, pedagogical content knowledge, subject-matter content, and learning in relation to participation in the school organisation (Hoekstra, Kuntz, \& Newton, 2017). In a study of teachers' professional development, which focused on pedagogy, Boyle, While and Boyle (2004) identified observation of colleagues and sharing practice as the most popular longer-term professional development activities. The study showed that a majority of the teachers who take part in such longer-term activities change their teaching practice.

What is particular for VET is that the subject-matter content is situated in specific communities of practice in working life. We discuss here the outcomes or values created from teachers' CPD concerning such subject-matter content, and the related pedagogical content knowledge, i.e. knowledge concerning how content based on worklife practices can be taught in VET. However, research concerning VET teachers' CPD is limited (de Rooij, as cited in Parsons, Hughes, Allinson, \& Walsh, 2009, p. 92) and has mainly focused on teaching competence (e.g. Bound, 2011; Messmann \& Mulder, 2011). Vähäsantanen, Hökkä, Eteläpelto, Rasku-Puttonen and Littleton (2008) studied identity negotiation among Finnish teachers in VET and in teacher education at university level. They showed that the teachers' agency within the organization is important for their commitment. Stephens (2015) discussed the professional development of teachers in career and technical education programmes in Michigan, with a focus on teachers with extensive experience from industry who are recruited as teachers and must develop pedagogical knowledge and skills. However, a study of both students' and teachers' views of what a "good VET teacher" is in Australia, for example, showed that both students and teachers consider pedagogical skills as well as expertise and experience from industry to be important (Smith \& Yasukawa, 2017). Thus, the boundary-crossing character of VET teachers' work seems to be important for good VET teaching. Hoekstra and Crocker (2015) show that interaction between working life and the educational context is important, and suggest that further investigations with this interaction in focus are required. In a later study from Canada, Hoekstra et al. (2017) showed that pedagogical content knowledge and pedagogy were most often in focus in everyday learning episodes among 27 instructors in vocational and professional education, while the subject-matter content was in focus more rarely. The work presented here contributes to this area of research, with a particular focus on VET teachers' CPD activities related to the vocational subject-matter contents and how up-to-date the outcome is. Some previous studies present results relevant to the work presented here, but prior research has mainly examined conditions for CPD, rather than the outcomes or value creation.

Vocational knowledge is the focus of Broad's (2013, 2015, 2016) studies of how VET teachers in further education colleges in the UK maintain and develop their occupa- 
tional expertise. Of 12 pre-defined CPD activities, reading books, journals, and online material was most common among the 57 respondents in the study. We will also discuss here "unintended CPD", and thus access to knowledge not "codified" for use in VET is particularly interesting. Different activities that provide CPD experience, in which teachers engage with more or less "tacit" or uncodified or semi-codified knowledge, are also included. Such activities include practicing, peer observation, shadowing, students' placements, involvement with professional bodies, educational trips, and hosting guest speakers. They include also attending courses and workshops (Broad, 2016). Three key drivers for CPD were identified: a passion for the subject/occupation, keeping occupational knowledge up-to-date, and improving teaching and learning. These drivers can be seen as perceived values of CPD. Broad (2013) discusses how teachers work hard to achieve these results, even in the face of organisational barriers. Thus, drivers for CPD are mainly to enhance knowledge and teaching, rather than to meet external requirements. Workload and funding are notable barriers. However, the main barrier seems to be the lacking of suitable networks, or the existence of only 'impoverished' networks, which may also be a result of teachers' workload and lack of time (Broad, 2015).

Lloyd and Payne (2012) have shown how conditions of employment have an impact on VET teachers' opportunities to maintain the knowledge and skills related to their initial occupation. For example, working part-time as a teacher provides a natural opportunity to continue to work in the initial occupation. Established structures and management support are other conditions that influence the VET teachers' possibilities and motivations to move between the practice of school and the practice of working life (Frisk, 2014; Opetushallitus, 2014). In a small-scale study, Fejes and Köpsén (2014) identified several constraints on VET teachers' participation in working life, i.e. constraints that make it difficult for teachers to maintain the occupational knowledge needed to prepare the vocational students for working life. VET teachers who do not maintain up-to-date vocational knowledge are, therefore, not competent to teach on the advanced courses of VET. Another aspect of this is how VET teachers value the different aspects of the dual professional competence. Nylund and Gudmundson (2017) found two types of identity among building and construction teachers - "craftsmen" and "teachers". The "craftsmen" (who were working as VET teachers) saw vocational knowledge and culture as more important than, and differentiated from, pedagogical knowledge related to a school culture; while "teachers" saw these types of knowledge as more closely associated.

Brennan Kemmis and Green (2013) showed a corresponding duality in a study of how Australian VET teachers view their pedagogy. The VET teachers expressed a strong connection to the workplace and the vocation, which in some cases resulted in tensions in relation to other categories of teacher who were not based in another, initial occupation.

A study from New Zealand presents an even more complex picture of the VET teacher, or "trade tutor". Maurice-Takerei (2016) describes a "multi-dimensional identity", that includes simultaneously being a bricoleur, an engineer, and a "kaitiaki" (a Maori concept). Thus, a VET teacher is a skilled practitioner who finds creative short-term solutions (a bricoleur), a structured and systematic innovator and planner (an engineer), and a "guardian, mentor and guide" (p. 128) who builds bridges between worlds and protects and passes on trade skills (a kaitiaki). 
Research in Sweden has provided more insight into the part of VET teachers' CPD that concerns vocational knowledge and identity. As mentioned above, the present study is part of a larger research project, presented above in the Introduction. The study of a national initiative to stimulate VET teachers' workplace-based CPD indicated that vocational area and the geographical region in which the VET teachers are employed influence the VET teachers' participation. Teachers from the areas of technology and construction were underrepresented among the participants, while the participation rate in industry arrangements among construction teachers was higher. Teachers from highly populated municipalities were overrepresented, and the type of municipality was the strongest predictor for recurrent participation (Andersson \& Köpsén, 2015, Köpsén \& Andersson, 2017). These studies of participation in the national initiative raised new questions, and the work presented here to examine VET teachers' participation in various CPD activities was initiated. The first analysis (Andersson \& Köpsén, 2017) showed, among other things, that reading is the most common CPD activity, and reading together with work in the teacher's initial occupation is also the activity in which the variation in performance can be explained to the highest degree. These results agree with those obtained by Broad (2016). Furthermore, longer work experience in the initial occupation increases the probability that a VET teacher is still active in the occupation, parallel to the work as a teacher. Longer teaching experience corresponds to a lower probability of this activity.

\section{The Study}

The present study uses a survey designed to measure CPD activities. The data have primarily been analysed using logistic regression modelling. Sub-sections 4.1-4.3 describe the questionnaire development and the data analysis.

\subsection{Questionnaire Development}

We developed a questionnaire to measure VET teachers' participation in CPD and the perceived value created from such activities. It was designed also to identify barriers and drivers for participation. Background data was collected from registry data, supplemented by the questionnaire.

As the theoretical perspective presented above indicates, learning through participation in relevant communities of practice is seen as central for VET teachers' development of occupational identity. Such participation involves boundary crossings between school and working life. Relevant variables, i.e. variables that can represent or explain participation in, and boundary crossing between, different communities of practice were identified.

Additional drivers of, and barriers to, participation were identified, and classified as institutional, situational, or dispositional (Cross, 1981).

Several types of CPD activity were considered. These activities had been identified in prior studies, or were based on the theoretical perspective. They were based on a preunderstanding of possible CPD activities and on conversations with VET teachers during 
the development of the questionnaire. The activities concern VET teachers' professional development in three ways. Firstly, in terms of crossing boundaries between school and working life; secondly, in terms of studying and learning, formally and informally; and thirdly, in activities in which teachers' knowledge is to be incorporated into teaching practices. This allowed eight activities to be identified, which were classified into three broad activity groups: relations to working life, vocational learning, and development activities. These activity groups are not used analytically in this article; they are simply used as structural aids.

The activities related to working life were: i) work in a workplace or own business, ii) study visits to workplaces, and iii) coordination of student placements or apprenticeships. The activities classified as vocational learning were: iv) participation in industry arrangements (such as conferences or short courses arranged by the industry); v) formal education; and vi) reading specialist and technical literature within the vocational subject area taught. The final group of activities were those aimed at the development of vocational teaching, and were: vii) the pursuit of projects together with industry representatives; and viii) work with pedagogical improvement. Three types of item were covered for each activity: i) whether, and how often, the teachers had performed the activity during the preceding two years, ii) the perceived created values or outcomes of the activity, and iii) the perceived drivers and barriers.

For each activity, six items related to three types of value were measured: values concerning vocational knowledge, networks in the industry, and teaching. These three values were central CPD outcomes in the theoretical framework described above. This includes knowledge/learning as a central aspect of the occupational identity developed by participation, networks as important for boundary crossings between school and workplaces, and teaching-related effects as a result of boundary crossings back to school. In other words, having specific vocational knowledge means that teachers have mastered the content of their teaching practice; the networks are crucial for the teacher's relationship to the occupational practice and possible boundary crossings; and teaching is the central activity in the present occupational practice of the VET teacher.

Eight items were presented for each activity relating to perceived drivers and barriers, concerning institutional, situational, and dispositional aspects (Cross, 1981). For example, we asked about the importance of support from the school organisation and the way teaching work is organised (institutional), about the teacher's family situation and the economic value in terms of income (situational), and about the personal interest and perceived need to develop occupational knowledge (dispositional).

Items concerning the teachers' vocational area of teaching were included in the background data, as was vocational area. This was to take the different types of vocational knowledge and practice that each vocation requires, and different institutional contexts. The length of experience in their initial occupations was included as a measure of previous participation in relevant communities of practice. During the development of the questionnaire, VET teachers were consulted on content, and the final questionnaire was assessed by experts from Statistics Sweden, whose proposals improved its quality. 


\subsection{Data Collection and Participants}

The survey was distributed by Statistics Sweden and respondents could choose to answer with paper and pen or over the internet. The sample was collected using stratified randomised sampling, with strata based on respondents' sex, age, and type of school. The initial sample consisted of 2,000 Swedish teachers working at upper secondary level, out of a population of 11,461 identified by Statistics Sweden. After two reminders, 982 answers had been received. After correcting for overlay, the final sample consisted of 886 valid responses, yielding a response rate of 47 percent.

Background data for the respondents were collected by Statistics Sweden from registry data. These data were selected to provide information about teachers' personal background and institutional and situational aspects of their present participation in the practices. The data included information on respondents' sex, educational training, length of teaching experience, type of school, type of employment, degree of employment as a teacher, and the type of municipality in which the teacher was active. Other data collected included age, type of school (publicly or privately owned), and type/level of training in the initial occupation. These were later excluded, as they had no significant influence on the analysis.

Among the 886 vocational teachers who responded and for whom survey and registry data were used in the analysis, 437 were women and 449 men. The distribution of the teachers in six vocational areas across sex is presented in Table 11 . The age of the respondents ranged from 23 to 78 years, with the average age being $48.7(S D=10.7)$; of these, 5.9 percent are 65 years or older, which is a common age of retirement in Sweden.

Table 1: Numbers of female and male teachers across the six different vocational areas

\begin{tabular}{llll}
\hline Vocational area & Female & Male & $\mathrm{N}$ \\
\hline Care & 132 & 19 & 151 \\
Construction & 7 & 91 & 98 \\
Practical-aesthetical & 144 & 49 & 193 \\
Service & 108 & 51 & 159 \\
Technology & 15 & 138 & 153 \\
Vehicles & 0 & 87 & 87 \\
\hline
\end{tabular}

There is a broad range of experience, measured as the number of years as a teacher, from one year to 41 years, with an average of $9.9(S D=8.3)$. Most of the teachers $(55 \%)$ work full time, and of the 45 percent who are employed part-time, nearly 70 percent $(69.9 \%)$ have a degree of employment of more than 50 percent.

\footnotetext{
${ }^{1}$ The survey data include information on vocational area for 818 of 886 teachers. A small number reported teaching in more than one area, which means that the total number of respondents in the table is 841
} 


\subsection{Data Analysis}

Logistic regression was used to model the perceived value. One model was constructed for each CPD activity and outcome, resulting in 24 models. The indexes for perceived value were constructed through indexes of averages - one for each of the eight activities across each perceived value with six items (scale 1-4) per activity. The indexes measure the perceived value related to the teachers' own vocational knowledge and skills, the improvement of their own teaching, and the development of their networks in the industry. The perceived values have been dichotomised into low value $(\leq 3)$ and high value $(>3)$. The distribution of the perceived value of the types of CPD activity and across vocational knowledge, teaching, and teachers' industrial network is shown in Table 2. The perceived values created from these activities (high/low) were tested against teacher training, teaching experience, and work experience from initial occupation. The type of municipality, respondent's sex, whether the tested activity had been performed at least once each year during the preceding years (each semester for reading), and institutional, situational and dispositional drivers and barriers were all included in the models.

The logistic regression models were run stepwise in SPSS (ver. 24) to remove variables. While the use of stepwise regression is problematic, in that variables are removed for mathematical reasons rather than theoretical ones, its use is justified in an exploratory study such as this, where the key interest is to explore variables that show influence rather than to test a theoretical model.

Table 2: Distribution of perceived value (high/low) for different types of CPD activity across scales (14) of vocational knowledge, improvement of teaching, and development of teacher's network

\begin{tabular}{|c|c|c|c|c|c|c|c|c|c|c|}
\hline \multirow[t]{2}{*}{ Activity group } & \multirow[t]{2}{*}{ CPD activity } & \multicolumn{3}{|c|}{ Vocational knowledge } & \multicolumn{3}{|c|}{ Teaching } & \multicolumn{3}{|c|}{ Networks } \\
\hline & & High & Low & $\mathrm{N}$ & High & Low & $\mathrm{N}$ & High & Low & $\mathrm{N}$ \\
\hline \multirow{3}{*}{$\begin{array}{l}\text { Relations to working } \\
\text { life through: }\end{array}$} & Work & 459 & 349 & 808 & 381 & 415 & 796 & 456 & 351 & 807 \\
\hline & Study Visits & 251 & 558 & 809 & 265 & 537 & 802 & 373 & 435 & 808 \\
\hline & Student Placements & 186 & 580 & 766 & 189 & 575 & 764 & 337 & 434 & 771 \\
\hline \multirow{3}{*}{$\begin{array}{l}\text { Vocational learning } \\
\text { through: }\end{array}$} & Industry Arrangements & 328 & 469 & 797 & 300 & 489 & 789 & 268 & 524 & 792 \\
\hline & Studying & 219 & 553 & 772 & 256 & 515 & 771 & 85 & 682 & 767 \\
\hline & Reading (semester) & 268 & 539 & 807 & 276 & 530 & 806 & 82 & 712 & 794 \\
\hline \multirow{2}{*}{$\begin{array}{l}\text { Development } \\
\text { activities: }\end{array}$} & Projects & 273 & 492 & 765 & 263 & 493 & 756 & 270 & 491 & 761 \\
\hline & Pedagogical Improvement & 202 & 549 & 751 & 314 & 433 & 747 & 120 & 617 & 737 \\
\hline
\end{tabular}


Some variables were rejected in all models. These were removed, and the models were rerun without them. The variables rejected were age, type of school (publicly or privately owned), and type/level of training in the initial occupation. The nature of teacher training had been formed into three categories based on the registry data: having a teaching degree, other teacher training, or no such training. The variables that measured experience, in both teaching and in the initial occupation, were divided into three categories: $\leq 3$ years, $4-7$ years, and $\leq 8$ years. The type of municipality was included as a geographical dimension, and based on an established categorisation of Swedish municipalities (Statistics Sweden, 2011, p. 14), here divided into four groups: The main large city areas, the other large city areas, highly populated municipalities, and sparsely populated municipalities. The respondent's sex rather than vocational area was used to avoid multicollinearity problems due to strong interactions between sex and vocational area, as well as the fact that some of the respondents were active in more than one vocational area.

From the survey, data on participation in the activities were used, as were indexes for dispositional, institutional and situational barriers and drivers. Participation differed between the activities (Table 3), and has been included in the analysis as a binary variable. Apart from reading, the respondent has been considered to have participated in an activity if it has been performed at least once per year in the preceding two years. For reading, every semester was used, due to the high frequency of the activity over two years. The indexes for barriers and drivers for each activity were constructed through a grouping of eight items (scale 1-5) into three indexes with average values for each.

Table 3: Participation in types of CPD activity at least a year (every semester for reading) among VET teachers

\begin{tabular}{llll}
\hline Activity group & CPD activity & Participation (\%) & N \\
\hline Relations to working & Work & 60.2 & 791 \\
life through: & Study Visits & 86.3 & 797 \\
& Student Placements & 80.8 & 791 \\
Vocational learning & Industry Arrangements & 64.0 & 789 \\
through: & Studying & 22.8 & 776 \\
& Reading (semester) & 80.6 & 789 \\
Development & Projects & 43.1 & 785 \\
activities: & Pedagogical Improvement & 68.2 & 793 \\
\hline
\end{tabular}

\section{Findings}

The perception of a high value differs between the activities (Table 2). The initial impression given by Table 2 is that differences in perceived values among CPD activities 
are as expected. For example, the perceived values concerning development of networks have a very low proportion of individuals who perceive a high value created from studying and reading, as these activities are more individual than linked to others. In contrast, the CPD activity of work generally has a high proportion of individuals who perceive a high value across vocational knowledge and networks. While these activities differ in their outcomes, high or low perceived value, the underlying factors may or may not differ. The perceived value creation in terms of vocational knowledge, improved teaching, and development of teachers' networks, have, therefore, each been tested against eight types of activity using stepwise logistic regression. The activities are here reported in three broad activity groups: relations to working life, vocational learning, and development activities. (As noted earlier, these groups are used to structure the results, and are not intended to be analytical.) The final model is presented for each regression, due to the number of models used (24) and the exploratory nature of the study. The number of iterations (steps) taken to reach the final model is reported for each model.

\subsection{Value Creation in Relation to Working Life}

A key component for VET teachers is the connection to the vocation and the working life, i.e. the communities of practice of their initial vocations (Andersson \& Köpsén, 2017; Köpsén, 2014). Activities included here are work in a workplace or own business, study visits to workplaces, and coordination of student placements or apprenticeships. Table 4-6 present the final regression models for the effects on high perceived value for vocational knowledge, teaching, and networks, for each activity ${ }^{2}$

For work, positive effects on the perceived value were found from the respondent being female, from having performed the activity more frequently, and from institutional and dispositional drivers. Teacher training was retained for vocational knowledge as well as teaching, though here the effect was generally negative for those with a teaching degree. The effect of the dispositional driver points towards individual factors, and performing the activity contributing to a higher perceived value. The positive effect of institutional drivers may be connected to the influence that the school has on the teaching position, relative to the opportunity to work in the initial occupation. The negative effect of teacher training for values created from work may be due to the fact that teacher training creates a value in its own right, which makes the impact of work less for those with a teaching degree than it is for those with other forms of training.

For study visits the models are fairly accurate, but the fits for teaching and network are rather poor. The interpretation of the models, therefore, should be taken with some care. That said, dispositional and situational drivers stand out as contributing factors to a high perceived value of study visits, while the respondent's sex has a positive contribution for teaching and networks. The type of municipality comes into effect for teaching, where large city areas have a negative effect. Teacher training has a negative effect for networks. As with working, the fact that the respondent's sex is important, as is also the nature of the drivers, points towards individual factors. It is noteworthy

\footnotetext{
${ }^{2}$ Blank spaces in the tables $4-11$ indicate variables that were not retained in the final models.
} 
here that performing the activity is not retained in the model. The poor fits of these models, however, mean that these results must be treated with some leniency, even though the results are consistent with the results of other activities. Student placements differ from study visits in that the performance of the activity is retained and that the respondent's sex generally is not, with the performance of activity and the respondent's sex having a positive effect for perceiving a high value. The type of municipality and the nature of teacher training have similar effects here as they had for study visits, in that the perceptions of value creation is lower for large cities, for teaching, while teacher training has a lower effect for networks. The final model for vocational knowledge has a reasonable accuracy, but the fit is poor and the model should be interpreted with caution.

Generally speaking, the models related to working life show that individual factors contribute to the creation of a high perceived value. Dispositional drivers stand out as consistent, with engaging in the activity and the respondent's sex being frequently retained. Teacher training (when retained) points towards a negative effect from having a teaching degree, whereas experience, both from teaching and work, is not retained in any model. This suggests that the teachers' individual motivations and performance of the activity, rather than experience (both teaching experience and experience of work in the initial occupation), have a general effect. The effect of the respondent's sex is probably connected to the strong effect of gendered subject areas.

Table 4: Final logistic regression models for working life: work

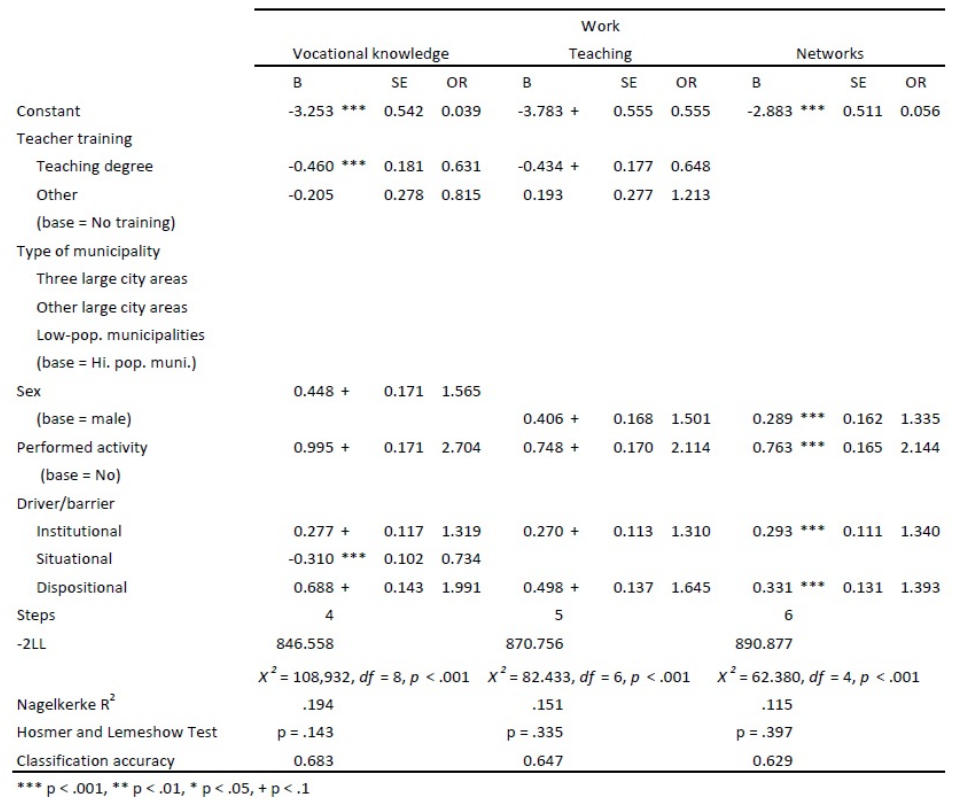


Table 5: Final logistic regression models for working life: study visits.

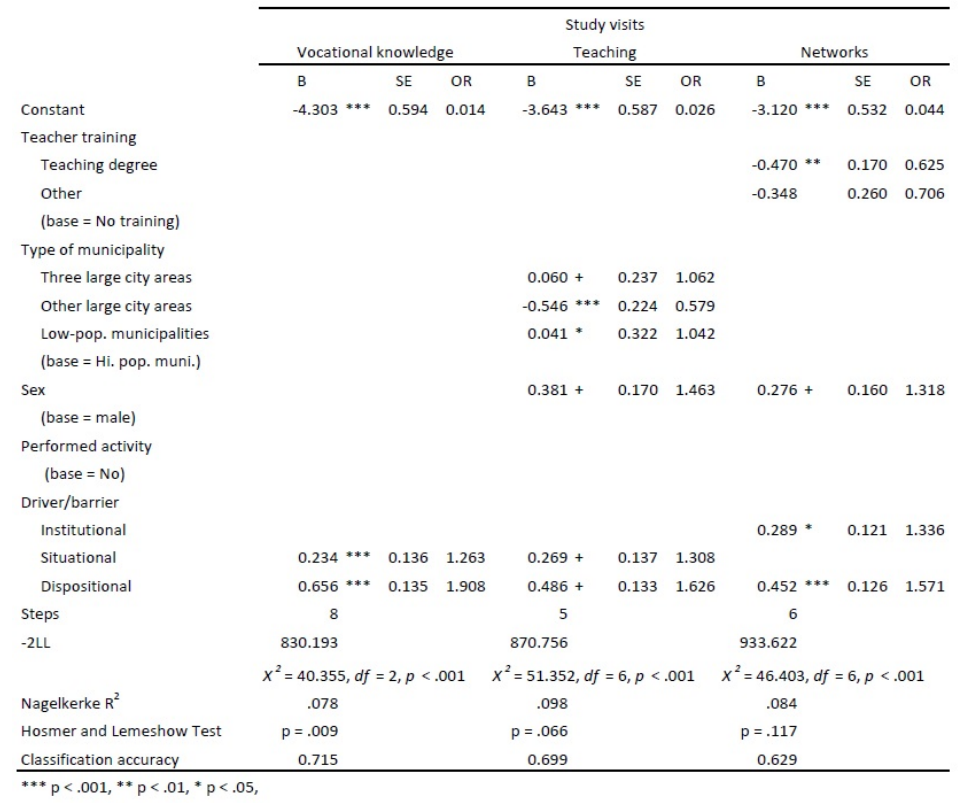

Table 6: Final logistic regression models for working life: student placements

\begin{tabular}{|c|c|c|c|c|c|c|c|c|c|}
\hline & \multirow{2}{*}{\multicolumn{3}{|c|}{ Vocational knowledge }} & \multicolumn{3}{|c|}{ Student placements } & \multirow{2}{*}{\multicolumn{3}{|c|}{ Networks }} \\
\hline & & & & Teach & hing & & & & \\
\hline & B & SE & OR & B & SE & OR & B & SE & OR \\
\hline Constant & $-5.255^{* * *}$ & 0.630 & 0.005 & $-4.912 * * *$ & 0.621 & 0.007 & $-3.089 * * *$ & 0.502 & 0.046 \\
\hline \multicolumn{10}{|l|}{ Teacher training } \\
\hline Teaching degree & & & & & & & $-0.220 * * *$ & 0.176 & 0.802 \\
\hline Other & & & & & & & -0.723 & 0.287 & 0.485 \\
\hline \multicolumn{10}{|l|}{ (base = No training) } \\
\hline \multicolumn{10}{|l|}{ Type of municipality } \\
\hline Three large city areas & & & & 0.181 & 0.267 & 1.198 & & & \\
\hline Other large city areas & & & & -0.388 & 0.251 & 0.679 & & & \\
\hline Low-pop. municipalities & & & & -0.322 & 0.381 & 0.725 & & & \\
\hline \multicolumn{10}{|l|}{ (base = Hi. pop. muni.) } \\
\hline Sex & & & & & & & $0.360 *$ & 0.168 & 1.434 \\
\hline \multicolumn{10}{|l|}{ (base = male) } \\
\hline $\begin{array}{l}\text { Performed activity } \\
\quad(\text { base }=\text { No) }\end{array}$ & $0.985 * * *$ & 0.355 & 2.677 & 0.675 * & 0.324 & 1.965 & $0.562 * *$ & 0.244 & 1.754 \\
\hline \multicolumn{10}{|l|}{ Driver/barrier } \\
\hline Institutional & & & & & & & $0.207+$ & 0.113 & 1.230 \\
\hline \multicolumn{10}{|l|}{ Situational } \\
\hline Dispositional & $0.816^{* * *}$ & 0.133 & 2.262 & $0.845^{* * *}$ & 0.134 & 2.328 & $0.404 * *$ & 0.125 & 1.498 \\
\hline Steps & 8 & & & 7 & & & 5 & & \\
\hline \multirow[t]{2}{*}{$-2 L L$} & 671.142 & & & 671.777 & & & 853.496 & & \\
\hline & $x^{2}=57.162, d f=$ & $=3, p<$. & 001 & $x^{2}=64.276, d f=$ & $=5, p<.0$ & .001 & $x^{2}=54.783, d f=$ & $=6, p<$. & .001 \\
\hline Nagelkerke $R^{2}$ & .125 & & & .139 & & & .107 & & \\
\hline Hosmer and Lemeshow Test & $\mathrm{p}=.037$ & & & $p=.106$ & & & $p=.926$ & & \\
\hline Classification accuracy & 0.756 & & & 0.767 & & & 0.622 & & \\
\hline
\end{tabular}




\subsection{Value Creation in Relation to Vocational Learning Activities}

It can be argued that continuing professional development requires an engagement with the subject matter, and thus three activities with such a focus are explored in this section: visiting industry arrangements such as conferences and workshops, studying in formal education, and reading literature relevant to the vocation. Table 7-9 present the results for these activities.

Factors that contribute to higher perceived value creation from industry arrangements are the respondent's sex and dispositional drivers for networks, and having performed the activity for vocational knowledge and networks. The high importance of dispositional drivers, together with that of performing the activity, suggest that individual actions and factors are important. Teacher training, with a teaching degree or some other form of training, has a negative effect on perceiving a high value, relative to those with no training. This may be due to those with formal education tending to teach in more theoretical areas. All municipalities with the exception of highly populated municipalities have a negative impact on perceiving a high value.

Dispositional drivers and the respondent's sex again show a positive contribution to perceiving a high value creation from formal study, as does having performed the activity of formal studies for teaching and networks. Here, teaching experience has a negative effect for teaching, which suggests that increased teaching experience leads to a lower value being perceived created from studies. Respondents may consider that study has been supplanted by teaching experience.

Reading, which in contrast to the other activities was measured per semester rather than per year, continues the trend of having dispositional factors and the respondent's sex contributing positively to a higher perceived value. This is also true for vocational knowledge and teaching, but not for networks. Further institutional drivers have a positive effect. Here, the effect of teacher training is that the effect of reading on networks is negative for those with formal education, whereas it is positive for those with informal training. Experience in teaching here shows a negative contribution to perceiving a high value for those with relatively short experience, while it is positive for those with longer than 8 years.

The models for vocational learning activities are overall similar to those of relationship to working life, in that dispositional drivers, respondent's sex and performing the activity have positive effects for a perceived high value creation. As with working life, work experience is not retained in any model, while teaching experience is retained in some, where it has a negative effect. 
Table 7: Final logistic regression models for vocational learning activities: industry arrangements

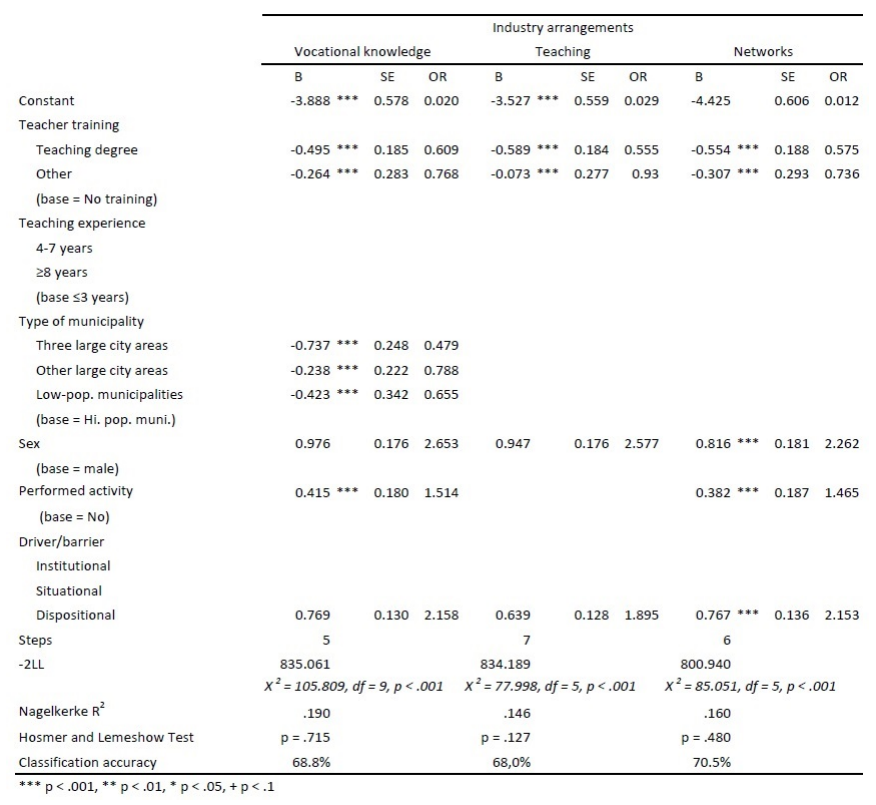

Table 8: Final logistic regression models for vocational learning activities: studying

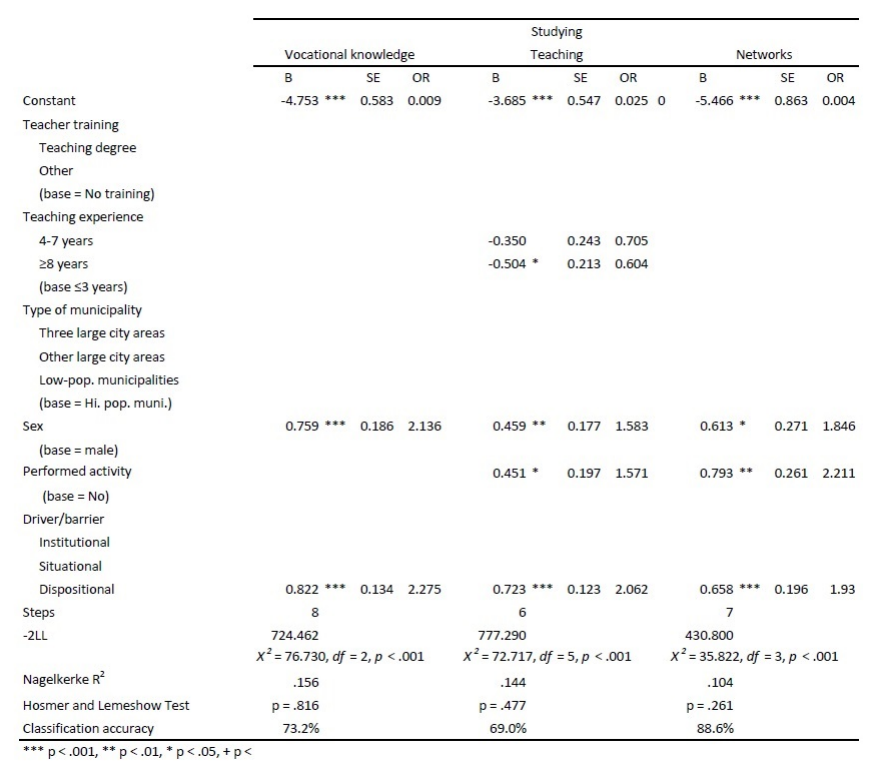


Table 9: Final logistic regression models for vocational learning activities: reading

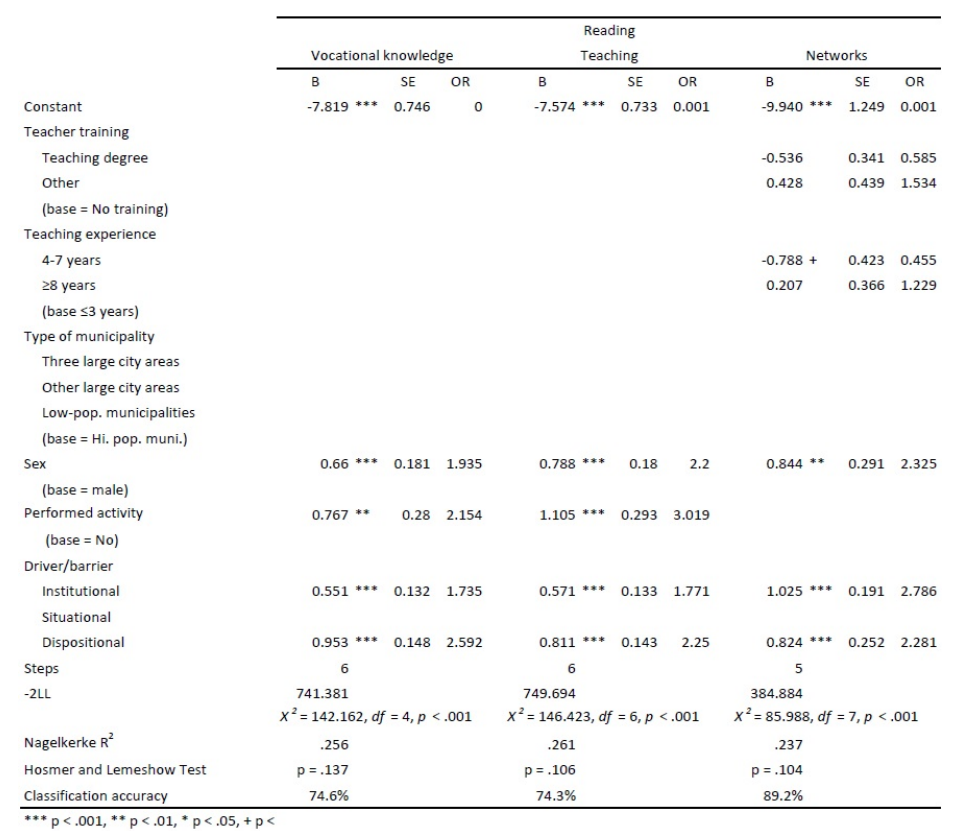

\subsection{Value Creation in Relation to Development Activities}

Teaching as a profession tends to involve activities that are aimed at developing the teaching of the subject contents. Two such development activities for VET teachers are working in projects with industry representatives, and pedagogical development. Table 10-11 present results from these two activities.

The final models for working in projects show that respondent's sex and performing the activity have a positive effect on perceiving high value creation, as have dispositional drivers. The reoccurrence of these confirms that they are central factors in the perception of high value creation. Teaching experience has a negative effect on perceiving high value creation, though it is significant only for those with longer than 8 years of experience. This negative effect may be the result of teaching experience supplanting the experience of projects, or of those with less teaching experience being more open, and valuing collaborations with actors outside school higher.

The final activity covered is pedagogical development, and dispositional factors are again retained in the models. Such factors have a positive effect for perceiving high value creation. Performing the activity has a positive effect for vocational knowledge, as it does for teaching. For networks, performing the activity is not retained while the respondent's sex is, where the effect is positive for female respondents. The pattern for this final activity is generally similar to that of other activities with dispositional drivers, sex and performance of the activity making positive contributions.

Results for overall development activities agree with the results from dispositional 
drivers: respondent's sex and performance of the activity are positive contributors, and retained teaching experience has a negative effect.

Table 10: Final logistic regression models for development activities: projects

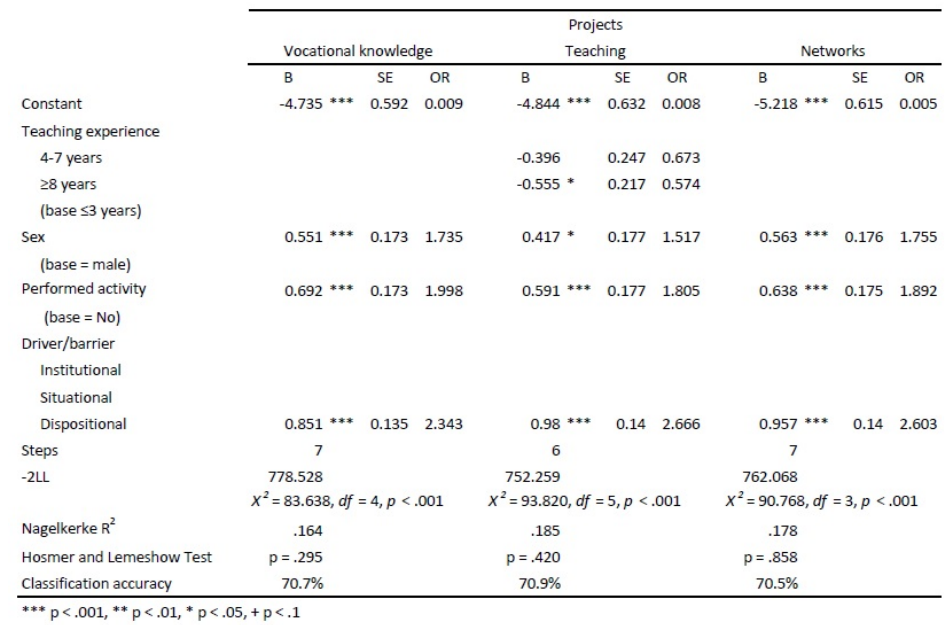

Table 11: Final logistic regression models for development activities: pedagogical development

\begin{tabular}{|c|c|c|c|c|c|c|c|c|c|}
\hline & \multicolumn{9}{|c|}{ Pedagogical development } \\
\hline & \multicolumn{3}{|c|}{ Vocational knowledge } & \multicolumn{3}{|c|}{ Teaching } & \multicolumn{3}{|c|}{ Networks } \\
\hline & B & SE & OR & B & SE & $\mathrm{OR}$ & B & $\mathrm{SE}$ & OR \\
\hline Constant & $-5.278 * * *$ & 0.658 & 0.005 & $-4.296 * * *$ & 0.565 & 0.014 & $-6.649 * * *$ & 0.859 & 0.001 \\
\hline \multicolumn{10}{|l|}{ Teaching experience } \\
\hline \multicolumn{10}{|l|}{ 4-7 years } \\
\hline \multicolumn{10}{|l|}{$\geq 8$ years } \\
\hline \multicolumn{10}{|l|}{ (base $\leq 3$ years) } \\
\hline Sex & & & & & & & $0.666^{* *}$ & 0.228 & 1.946 \\
\hline \multicolumn{10}{|l|}{ (base = male) } \\
\hline Performed activity & $0.454^{*}$ & 0.221 & 1.575 & $0.736 * * *$ & 0.197 & 2.088 & & & \\
\hline \multicolumn{10}{|l|}{ (base $=\mathrm{No}$ ) } \\
\hline \multicolumn{10}{|l|}{ Driver/barrier } \\
\hline \multicolumn{10}{|l|}{ Institutional } \\
\hline \multicolumn{10}{|l|}{ Situational } \\
\hline Dispositional & $0.942 * * *$ & 0.149 & 2.566 & $0.836^{* * *}$ & 0.131 & 2.307 & $1.087^{* * *}$ & 0.191 & 2.966 \\
\hline Steps & 8 & & & 8 & & & 8 & & \\
\hline \multirow[t]{2}{*}{$-2 L L$} & 709.447 & & & 813.19 & & & 518.296 & & \\
\hline & $X^{2}=54.981, d f=$ & $=3, p<$. & .001 & $x^{2}=68.065, d f$ & $2, p<$. & 001 & $X^{2}=51.948, d f=$ & $2, p<$. & 001 \\
\hline Nagelkerke $R^{2}$ & .118 & & & .135 & & & .132 & & \\
\hline Hosmer and Lemeshow Test & $\mathrm{p}=.303$ & & & $\mathrm{p}=.073$ & & & $\mathrm{p}=.138$ & & \\
\hline Classification accuracy & $72.1 \%$ & & & $66.3 \%$ & & & $83.5 \%$ & & \\
\hline
\end{tabular}




\subsection{Summarizing Value Creation}

Overall, some factors that determine the perceived value creation from CPD activities are retained in the logistic regression models. Dispositional drivers are retained in all 24 final models, which leads us to conclude that individual drivers are a central component for perceiving a high value. Another factor that is often retained is respondent's sex, where females consistently perceive a higher value than males. However, it should be noted that there is an imbalance between sex and vocational area (Table 1), and sex was included in the models presented rather than vocational area, in order to avoid multicollinearity. Thus, the importance of sex should be interpreted with some care as the result is probably a consequence of not only of the respondent's sex but also of vocational area.

Performing a CPD activity is another factor that is often retained, and when retained it has a positive contribution. This suggests that performance of related activities is linked to the perception of value. This is as expected, since the experience of a CPD activity should be part of forming a value for the said activity. The results suggest that performing the activity generally has a positive contribution to a perception of value.

Some factors are frequently not retained in the final models. Interestingly, these are factors related to the training and experience of the teacher, both in teaching and occupational work. The effect that such factors have on the perception of high value, when seen, is generally negative.

\section{Discussion}

We have seen that individual factors are important for the perceived value of different activities for VET teachers' professional development concerning vocational subject-matter contents. But how can we understand the differences in perceived values? VET teachers have been described as (ideally) having a "double identity", being both a craftsman of a vocation and a teacher (Fejes \& Köpsén, 2014; Nylund \& Gudmundson, 2017). This study has focused on the vocational aspect of the identity and how to keep up-to-date. Value creation, however, is related to the "complete" identity of the teacher, and we have analysed values in relation to vocational knowledge, to the teachers' networks in industry, and to length of teaching experience. These different types of value are not separate but interrelated, as are the different aspects of the identity.

The results presented here show, in particular, that dispositional drivers are important for professional development, while institutional drivers generally have a weaker influence. The factors behind the dispositional drivers remain to be analysed in greater detail. Thus, it is possible to increase the opportunities for professional development among teachers by changes in the organisation of vocational education and training, and in this way exploiting the potential in teachers' agency identified by Vähäsantanen et al. (2008) to make the institutional factors important and create value among the teachers. These organisational changes should reduce barriers to boundary crossing between school and working life. 


\subsection{The Segregated Labour Market Reflected in VET}

We have also seen that a teacher's sex is a factor that influences the perceived values. It is possible that dispositional factors differ between women and men, in addition to situational factors related to the family and different roles as a family member. Further analysis of these factors is beyond the scope of the present study. It is, however, necessary to question what the imbalance between vocational areas concerning female/male teachers (and workers) means for the results presented here. The imbalance may give rise to an interaction between the variables sex and vocational area that we cannot analyse in depth with the data we have available. Female and male VET teachers are over-represented in some vocational areas that are also traditionally segregated in the Swedish labour market.

As an example, female teachers are over-represented in the area of care. This raises the possibility of a complex interaction between different types of factor. The broad care sector includes child care, healthcare, and elderly care. These areas are not only dominated by female employees, but they differ from most other vocational areas in terms of learning and knowledge. More precisely, it is more common that the VET teachers in these areas have a higher educational level than the vocation for which they are training students. In most other areas in Swedish VET, the teachers come from the vocation for which they are teaching. Teachers in child care are typically pre-school teachers, and they are teaching child minders-to-be. Similarly, teachers in healthcare and elderly care are nurses and social workers, and they are teaching assistant nurses-tobe. Thus, all these teachers have studied in higher education for their initial occupation. This background of teachers may foster a different attitude to participation in activities that lead to professional development, when compared with teachers without higher education for their initial vocation. It is, therefore, reasonable to suggest that female VET teachers have a more positive attitude to the value creation of various learning activities. The influence of sex, vocational area and type of training among teachers, however, remains to be analysed and understood.

\subsection{Influence of Experience on Teachers' Identities}

A somewhat surprising finding is that the length of experience from the initial occupation has only a limited influence on the perceived value of different CPD activities. We have seen earlier (Andersson \& Köpsén, 2017) that teachers with longer experience of the initial occupation are more likely to carry out at least one type of the boundary-crossing CPD activities that we analyse, and that they are more likely to cross the boundaries to the work-life practices to work there. However, the length of such experience does not have the same influence on the perceived values of the activity. A possible explanation appears when we consider the need of teachers to keep up-to-date in the industry. The requirements to be able to participate in working life and keep up-to-date are constantly developing, at different paces in different areas. All VET teachers will probably see the value of and need for CPD to remain up-to-date, independent of the length of their work-life experience. The latter, however, does affect the probability of actual boundary 
crossing and participation.

Another finding is that the length of experience as a teacher also affects how VET teachers value CPD. Teachers with longer teaching experience are less likely to see the value of the types of CPD activity that we have analysed. This raises the question of how a teacher retains an identity from the initial occupation. Does long experience as a teacher weaken the connection to the initial occupation? This is not unlikely, and supports the conclusion that it is important for VET institutions to stimulate and organise teachers' CPD, for newcomers and for old-timers in the community of VET teachers.

\subsection{The Effect of Participation on Value}

The findings show that participation is important. Perceived value is clearly higher among those who had performed the different activities analysed. This confirms that it is important for VET teachers to have the opportunity to carry out various activities with "CPD potential" (Fraser et al., 2007). Institutional factors are important also here, especially for those teachers who do not have dispositional drivers strong enough to overcome institutional barriers, but still need competence development to do a good job in VET. Institutional factors may be particularly important for participation in longer-term CPD activities, which are more likely to create value in terms of changes in teaching practice (Boyle et al., 2004).

However, we should not take for granted that performing an activity is the cause, and the perceived value an effect. It is possible that carrying out an activity is the effect of a perceived value - VET teachers are probably more likely to carry out activities that they believe will have a positive influence on their professional development.

\subsection{Reflections on Method}

We have used a dichotomy of value creation (high/low), and this means that some nuance is lost. In reality, perceived value is a gradient, and our measure is rather coarse. Nevertheless, the study provides important insights in an area in which few studies have been conducted.

The properties we have studied leave some degree of variability in the perceived values unaccounted for, and other factors may be important. For example, the sociability of a teacher (e.g. ability to connect and create networks) may have an effect. The different levels of professionalism between different vocational areas may also have an effect. We have only discussed the influence of area segregation with regard to sex, and its possible interaction with educational background, but other factors depend on differences in practices between vocational areas.

Future studies should develop the instruments to include other factors not covered here. This exploratory study was limited to a pre-defined set of activities that we believed contributed to VET teachers' professional development, and a number of predefined factors that we believed influenced the perceived values of such activities. Other activities and factors are important in understanding the complex pattern of CPD among 
VET teachers. This quantitative study is part of a larger research project (see Andersson \& Köpsén, 2015, 2017; Köpsén \& Andersson, 2017). Forthcoming findings based on interviews with VET teachers will probably provide deeper insights into specific aspects of the topic. Here, we measured three types of possible value of the different activities. To distinguish and highlight different aspects of the value of $\mathrm{CPD}$, and what is valuable for the work of a VET teacher, helps us to understand CPD from one perspective. Further studies will view the topic with a more holistic perspective, and in this way achieve deeper understanding.

\section{Conclusions}

We have analysed several types of CPD activity to find out their value for teachers' vocational knowledge, ability to teach, and networks. These three components of VET teachers' professional action are important and interrelated. In order to work as a VET teacher, it is necessary to have a connection to a professional network, knowledge of how to perform the tasks within the field, and an ability to teach. Thus, all three are different "expressions" of what it means to be a VET teacher. As such, many CPD activities may contain components of all three values. For example, the most common of the activities we have analysed is reading. And while it is clear that reading can increase knowledge in the context of the community of practice of the vocation, it is connected also to the ability to interact with professionals active in the field, and to stimulating reflection on what and how to teach a subject.

Dispositional factors are significant, and this leads us to discuss the significance of this for the VET teacher identity. To what extent do the respondents identify as a teacher in a vocational subject, and to what extent as a vocational practitioner who teaches? This is a crucial question in the potential dual professional identity of VET teachers (Fejes \& Köpsén, 2014). The present study focuses on one side of the coin the professional competence and identity related to the teachers' initial occupation but the analysis shows that the two sides are intertwined. It is not a matter of being a vocational practitioner or a teacher - but of being, remaining, and developing as a boundary-crossing and bridge-building vocational teacher (Maurice-Takerei, 2016).

The community of teaching is crucial for this to happen (Lloyd \& Payne, 2012). The way in which the work in school is organised, and how contacts with practitioners within the vocational practices outside school are maintained and structured are important. The teacher is presently the driver for maintaining and building these connections through various types of boundary crossing and activity. Other actors in school and working life, however, can enable the professional development of VET teachers through measures that create $\mathrm{CPD}$ value among them.

\section{References}

Akkerman, S. F., \& Bakker, A. (2011). Boundary crossing and boundary objects. Review of Educational Research, 81(2), 132-169. 
Andersson, P., \& Köpsén, S. (2015). Continuing professional development of vocational teachers: Participation in a Swedish national initiative. Empirical Research in Vocational Education and Training, 7(7), 1-20, doi: 10.1186/s40461-015-0019-3

Andersson, P., \& Köpsén, S. (2017). Maintaining competence in the initial occupation: Activities among vocational teachers. Vocations and Learning. doi: 10.1007/s12186017-9192-9

Bolam, R., \& McMahan, A. (2004). Literature, definitions and models: Towards a conceptual map. In C. Day, \& J. Sachs (Eds.), International handbook on the continuing professional development of teachers (pp. 33-63). Maidenhead: Open University Press.

Bound, H. (2011). Vocational education and training teacher professional development: Tensions and context. Studies in Continuing Education, 33(2), 107-119.

Boyle, B., While, D., \& Boyle, T. (2004). A longitudinal study of teacher change: what makes professional development effective? The Curriculum Journal, 15(1), 45-68.

Brennan Kemmis, R., \& Green, A. (2013). Vocational education and training teachers' conceptions of their pedagogy. International Journal of Training Research, 11(2), $101-121$.

Broad, J. H. (2013). Doing it for themselves: A network analysis of vocational teachers' development of their occupationally specific expertise. EdD thesis. London: Institute of Education, University of London.

Broad, J. H. (2015). So many worlds, so much to do: Identifying barriers to engagement with continued professional development for teachers in the further education and training sector. London Review of Education, 13(1), 16-30.

Broad, J. H. (2016). Vocational knowledge in motion: rethinking vocational knowledge through vocational teachers' professional development. Journal of Vocational Education \&3 Training, 68(2), 143-160.

Brockmann, M., Clarke, L., Méhaut, P, \& Winch, C. (2008). Competence-based vocational education and training (VET): The cases of England and France in a European perspective. Vocations and Learning, 1(3), 227-244.

Cross, K. P. (1981). Adults as learners. San Francisco: Jossey-Bass.

Day, C., \& Sachs, J. (2004). Professionalism, performativity and empowerment: Discourses in the politics, policies and purposes of continuing professional development. In C. Day, \& J. Sachs (Eds.), International handbook on the continuing professional development of teachers (pp. 3-32). Maidenhead: Open University Press.

Eraut, M. (2007). Learning from other people in the workplace. Oxford Review of Education, 33(4), 403-422.

Fejes, A., \& Köpsén, S. (2014). Vocational teachers' identity formation through boundary crossing. Journal of Education and Work, 27(3), 265-283.

Fraser, C., Kennedy, A., Reid, L., \& Mckinney, S. (2007). Teachers' continuing professional development: contested concepts, understandings and models. Journal of In-service Education, 33(2), 153-169.

Frisk, T. (2014). Guide for the implementation of vocational teachers' work placement periods. Helsinki: The Finnish National Board of Education.

Gessler, M. (2017). The lack of collaboration between companies and school in the 
German dual apprenticeship system: Historical background and recent data. International Journal for Research in Vocational Education and Training, 4(2), 164-195.

Grollmann, P. (2008). The quality of vocational teachers: Teacher education, institutional roles and professional reality. European Educational Research Journal, 7(4), $535-547$.

Hoekstra, A., \& Crocker, J. R. (2015). ePortfolios: Enhancing professional learning of vocational educators. Vocations and Learning, 8(3), 353-372.

Hoekstra, A., Kuntz, J., \& Newton, P. (2017). Professional learning of instructors in vocational and professional education. Professional Development in Education, DOI: 10.1080/19415257.2017.1280523

Köpsén, S. (2014). How vocational teachers describe their vocational teacher identity. Journal of Vocational Education \& Training, 66(2), 194-211.

Köpsén, S. (2014). How vocational teachers describe their vocational teacher identity. Journal of Vocational Education \& Training, 66(2), 194-211.

Lave, J., \& Wenger, E. (1991). Situated learning: Legitimate peripheral participation. Cambridge: Cambridge University Press.

Lloyd, C., \& Payne, J. (2012). Raising the quality of vocational teachers: Continuing professional development in England, Wales and Norway. Research Papers in Education, 27(1), 1-18.

Maurice-Takerei, L. (2016). The bricoleur, the engineer and the kaitiaki: Reconceptualising the work of VET educators. International Journal of Training Research, 14(2), 119-130.

Messmann, G., \& Mulder, R. H. (2011). Innovative work behaviour in vocational colleges: Understanding how and why innovations are developed. Vocations and Learning, 4(1), 63-84.

Nylund, M., \& Gudmundson, B. (2017). Lärare eller hantverkare? Om betydelsen av yrkeslärares yrkesidentifikation för vad de värderar som viktig kunskap på Byggoch anläggningsprogrammet [Teacher or craftsman? The importance of vocational teachers' professional identification for what they regard as important knowledge in the Building and construction programme]. Nordic Journal of Vocational Education and Training, 7(1), 64-87.

Opetushallitus. (2014). Examensmästare, utbildningsprogram [Master of competencebased qualifications, curriculum]. Helsinki: Opetushallitus [Finnish National Board of Education].

Parsons, D., Hughes, J., Allinson, C., \& Walsh, K. (2009). The training and development of VET teachers and trainers in Europe. In Cedefop (Ed.), Modernising vocational education and training, fourth report on vocational education and training research in Europe: synthesis report (pp. 71-141). Luxembourg: Publications Office of the European Union.

Robson, J., Bailey, B., \& Larkin, S. (2004). Adding value: Investigating the discourse of professionalism adopted by vocational teachers in further education colleges. Journal of Education and Work, 17(2), 183-195.

Smith, E., \& Yasukawa, K. (2017). What makes a good VET teacher? Views of Australian VET teachers and students. International Journal of Training Research, 
15(1), 23-40.

Statistics Sweden. (2011). Regionala indelningar $i$ Sverige den 1 januari 2011 [Regional classifications in Sweden 1. January 2011]. örebro: Statistics Sweden.

Stephens, G. E. (2015). Uncertified and teaching: Industry professionals in career and technical education classrooms. International Journal for Research in Vocational Education and Training, 2(2), 119-135.

Vähäsantanen, K., Hökkä, P., Eteläpelto, A., Rasku-Puttonen, H., \& Littleton, K. (2008). Teachers' professional identity negotiations in two different work organisations. Vocations and Learning, 1, 131-148.

Wenger, E. (1998). Communities of Practice: Learning, meaning, and identity. Cambridge: Cambridge University Press.

Wenger, E., Trayner, B., \& de Laat, M. (2011). Promoting and assessing value creation in communities and networks: A conceptual framework. Heerlen: Ruud de Moor Centrum, Open Universiteit.

Wenger-Trayner, E., Fenton-O'Creevy, M., Hutchinson, S., Kubiak, C., \& WengerTrayner, B. (2015). Learning in landscapes of practice: Boundaries, identity, and knowledgeability in practice-based learning. Abingdon: Routledge.

\section{Biographical Notes}

Dr Per Andersson is a professor of education at the Department of Behavioural Sciences and Learning at Linköping University, Sweden. His research interests focus on recognition of prior learning, the professional development of vocational teachers, and marketization of adult education.

Dr Mattias Hellgren is a senior lecturer of sociology at the Department of Behavioural Sciences and Learning at Linköping University, Sweden. His research interests focus on learning, work and time-use.

Dr Susanne Köpsén is an associate professor of education at the Department of Behavioural Sciences and Learning at Linköping University, Sweden. Her research interests focus on vocational education, particularly teaching, teacher identity and the professional development of vocational teachers.

\section{Acknowledgement}

Grant 2013-2378 from the Swedish Research Council has made this study possible. 